\title{
Blood Profile of Quails (Coturnix coturnix japonica) Fed Ration Containing Silkworm Pupae (Bombyx mori) Powder Extract
}

\author{
N. Anggraeni ${ }^{a^{*}}$, A. Farajallah ${ }^{b}, \&$ D. A. Astutic \\ aStudy Program of Animal Bioscience, Graduate School, Bogor Agricultural University \\ ${ }^{b}$ Department of Biology, Faculty of Mathematics and Natural Science, Bogor Agricultural University \\ ${ }^{b}$ Department of Nutrition and Feed Technology, Faculty of Animal Science, Bogor Agricultural University \\ Jalan Agatis, Kampus IPB Darmaga, Bogor 16680, Indonesia \\ (Received 17-04-2015; Reviewed 03-06-2015; Accepted 10-11-2015)
}

\begin{abstract}
The aim of this research was to assess the use of silkworm pupae (Bombyx mori) powder extract on the blood cells and hematological variables of quails (Coturnix coturnix japonica). The treatments consisted of $\mathbf{R} 0=$ isoenergy and isoprotein ration without pupae powder extract, $\mathrm{R} 1=$ isoenergy and isoprotein ration $+1 \%$ of pupae powder extract, $\mathrm{R} 2=$ isoenergy and isoprotein ration $+10 \%$ of pupae powder extract, $\mathrm{R} 3=$ isoenergy and isoprotein ration $+1 \%$ of residue of pupae powder extract, R4= isoenergy and isoprotein ration $+10 \%$ of residue of pupae powder extract, $R 5=$ isoenergy and isoprotein ration $+1 \%$ of pupae powder, and $R 6=$ isoenergy and isoprotein ration $+10 \%$ of pupae powder. The variables measured were blood cell and hematological profiles including the number of leukocytes, erythrocytes, and leukocytes differentiation. Immune response was observed at 12, 24, and $48 \mathrm{~h}$ by counting the white blood cells type. The results showed that feed consumption ranged 79.19-154.70 g/quail/wk and the body weight was 71.45-149 g/quail. The addition of pupae extract at a dose of $10 \%$ in the diet significantly $(P<0.05)$ increased the number of quail white blood cells. The addition of pupae extract, pupae powder residue, and pupae powder in the ration did not significantly affect the number of quail erythrocytes, hemoglobin, and PCV (packed cell volume). Mean number of white blood cells increased during $24 \mathrm{~h}$ after treatment of $10 \%$ pupae powder extract (R2) and decreased at the $48^{\text {th }} \mathrm{h}$. It is concluded that the value of leukocytes, lymphocytes, monocytes, and heterophile increased in quails supplemented with $10 \%$ pupae powder extract (R2).
\end{abstract}

Key words: quail, silk worm pupae powder, the immune system, white blood cells

\section{ABSTRAK}

Tujuan penelitian ini ialah mengkaji pengaruh penggunaan ekstrak tepung pupa ulat sutera (Bombyx mori) pada sel darah dan peubah hematologi puyuh (Coturnix coturnix japonica). Perlakuan terdiri atas $\mathbf{R} 0=$ ransum isoenergi dan isoprotein tanpa ekstrak tepung pupa, $\mathbf{R} 1=$ ransum isoenergi dan isoprotein $+1 \%$ ekstrak tepung pupa, $R 2=$ ransum isoenergi dan isoprotein $+10 \%$ ekstrak tepung pupa, $\mathrm{R} 3=$ ransum isoenergi dan isoprotein $+1 \%$ residu ekstrak tepung pupa, $\mathrm{R} 4=$ ransum isoenergi dan isoprotein $+10 \%$ residu ekstrak tepung pupa, $R 5=$ ransum isoenergi dan isoprotein $+1 \%$ tepung pupa, dan $\mathrm{R} 6=$ ransum isoenergi dan isoprotein $+10 \%$ tepung pupa. Peubah yang diamati adalah profil hematologi meliputi: jumlah leukosit, eritrosit, dan diferensiasi leukosit. Respons kekebalan tubuh diamati pada 12, 24, dan 48 jam setelah pemberian pakan dengan menghitung jenis sel darah putih. Hasil penelitian menunjukkan bahwa konsumsi pakan berkisar 79,19-154,70 g/puyuh/minggu dan bobot badan puyuh memiliki rataan 71,45-149 g. Penambahan ekstrak pupa dosis 10\% dalam ransum nyata $(P<0,05)$ meningkatkan jumlah sel darah putih puyuh. Penambahan ekstrak tepung pupa, residu ekstrak tepung pupa, dan tepung pupa dalam ransum tidak berpengaruh pada jumlah eritrosit puyuh, hemoglobin, dan PCV (packed cell volume). Jumlah rata-rata sel darah putih meningkat selama 24 jam setelah penambahan $10 \%$ ekstrak tepung pupa (R2) dan menurun pada jam ke-48. Disimpulkan bahwa ada peningkatan nilai leukosit, limfosit, monosit, dan heterofil pada puyuh dengan menambahkan 10\% ekstrak tepung pupa (R2).

Kata kunci: puyuh, sel darah putih, sistem kekebalan tubuh, tepung pupa ulat sutera

*Corresponding author:

E-mail: anggibsh@gmail.com 


\section{INTRODUCTION}

Insects have great potential as sources of food and feed as well as a source of nutrients that is comparable to meat and fish and also can be a source of animal protein as the main stay protein in the future for the purposes of poultry farming and fish farming (Usub et al., 2008; Oh et al., 2012; Rumpold \& Schluter, 2013). The utilization of some insects such as silkworms and bees for large-scale production with the use of technology was done to anticipate the problem of global food and feed supply (Vantomme et al., 2010; Huis et al., 2013).

Another potential owned by insects is the discovery of a various bioactive substances with beneficial characteristics (Hirose et al., 2013). These substances included compounds with diverse pharmacological properties, including anti-cancer, anti-tumor, anti-viral, and antimicrobial as well as the capacity to boost the immune system against various diseases in human, livestock, poultry, and fish (Chernysh et al., 2002). Insects are not only useful as a source of animal protein in food production as well as feed, but they provide benefits in the pharmacological and medical areas which are able to protect animals and livestock against various risks of many diseases.

In the life cycle of insects, the eggs will hatch into larvae, pupae, and adult metamorphosis. In the stage of insect metamorphosis, pupae under fasting conditions to grow in the cocoon (protective hard). Silkworm cocoon thread is used for spinning into yarn silk, while the pupae are used as animal feed cultivation. Cocoon production for silk in Indonesia since the 2005-2009 period reached 166 tons, which produced about 23 tons of yarn. The wastes produced from the process were around 143 tons.

In some countries such as Korea, Japan, and China pupae are used to produce snacks, canned food, alternative foods for diabetics, candles and beauty products such as soap and hair tonic (Yi et al., 2010). Pupae silkworms can be made into flour pupae that can be used as an ingredient in the manufacture of complementary cookies (crackers and flakes), sponge cake, and nuggets (Astuti \& Kusharto, 2009). In addition, the pupae silkworm can be utilized as a bioreactor in the development of antiviral agents and as an immunostimulant in vertebrates (Yao et al., 2006; Swevers et al., 2013; Yeo et al., 2013).

The addition of insect pupae powder on red sea bream feed could boost immune activity against pathogenic bacteria (Ido et al., 2015). Powder extract of Bactrocera cucurbitae pupae was known to activate the innate immunity on rat macrophage cells (Ohta et al., 2014). This immunostimulatory effect was identified and it was derived from the active ingredient in the form of polysaccharides contained in the body of the pupae (Ohta et al., 2014). Silkworm pupae contained polysaccharides $(27.9 \%)$ (Long et al., 2007) and high protein (55.6\%) with a balanced amino acid (Zhou \& Han, 2006; Tomotake et al., 2010).

Immunostimulatory effect of silkworm pupae was identified from the polysaccharide contents. High molecular weight polysaccharide can activate the innate immune system. The polysaccharide is the site identifier (marker). Dipterose polysaccharide is synthesized by the Diptera insect pupae such as melons fly and has a molecular weight of $1.01 \times 10^{6} \mathrm{~mol} \%$. Similarly, it occurs also in insect Lepidoptera such as silkworm, polysaccharides molecular components, namely silk rose, that is synthesized in the pupae and has a molecular weight of $3.15 \times 10^{5} \mathrm{~mol} \%$. The composition of silkrose and dipterose consist of nine monosaccharides i.e., D-glucose, D-mannose, D-galactose, D-ribose, L-rhamnose, L-fucose, D-glucoronic acid, N-acetyl-D-glucosamine and N-acetyl-D-galactosamine (Ohta et al., 2014). Silkrose is ethanol-soluble polysaccharide group, so that silkrose bioactive substances can be obtained from the extraction of silkworm pupae powder with ethanol solvent.

L-rhamnose is one component of dipterose with the highest molar ratio as compared to the other monosaccharides. At silkrose, the highest monosaccharide component is D-Galactose with molar ratio reached $48.9 \%$. L-Rhamnose can be found in natural organic components such as flavonoids, terpenoids and saponins (Ohta et al., 2014). Saponins in a particular dosage are secondary compounds that can play a role as immunostimulant. Bomford (1980) reported that saponins can function resemble a membrane antigen of polysaccharide cell at the outside of the cell membrane and it is used as the site identifier (marker) in the immune system of vertebrates.

Dipterose and Silkrose were obtained from Musca domestica, melon fly, Hermetia illucens, Antheraea yamamai and Bombyx mori and were able to activate the innate immune response against pathogenic microorganisms and viral infections (Ohta et al., 2014; Ido et al., 2015). Conversely the waste of silkworm pupae in unrefined pupae powder will make some rat macrophage cells die (Ido et al., 2015). The ability of bioactive substances owned by the insects in activating the immune response against pathogens and viral infections in fish and mammals, become the reason to conduct a research to assess the use of silkworm pupa powder extract ( $B$. mori) on the blood profile of quail (Coturnix coturnix japonica).

\section{MATERIALS AND METHODS}

A total of 70 laying quails (Coturnix coturnix japonica) with the age of 4 weeks and average body weight of $76.36 \mathrm{~g}$ were used in this study and half of them (35 laying quails) were used for blood profile analysis. Raw materials used to formulate the experimental ration were corn, rice bran, soybean meal, fish meal, palm oil, $\mathrm{DCP}, \mathrm{CaCO}_{3}, \mathrm{NaCl}$, Premix, DL-Methionine, and silkworm pupae powder. Additional feed was given in the form of silkworm pupae powder, residue of silkworm pupae powder extraction and pupae powder extraction on the prescribed dose. Pupae powder extraction refers to the maceration extraction method with $95 \%$ ethanol as a solvent (Liu \& Zhang, 2006). Feed rations were prepared with isoenergy and isoprotein i.e. the energy content of $2950 \mathrm{kcal} / \mathrm{kg}$ and protein content of $18 \%$ (Table 1) (Leeson \& Summers, 2005). The experimental quails were maintained for 8 weeks, with details of treatment 
were first week for environmental adaptation, second week for control ration adaptation (R0), third week for additional treatment rations, and the last five weeks without ration treatments (R0). Rations and water were given ad libitum.

This study used a completely randomized design with 7 treatments and 5 replications. The treatments were $\mathrm{R} 0=$ isoenergy and isoprotein ration without pupae powder extract (control), R1= isoenergy and isoprotein ration $+1 \%$ pupae powder extract, $\mathrm{R} 2=$ isoenergy and isoprotein ration $+10 \%$ pupae powder extract, $\mathrm{R} 3=$ isoenergy and isoprotein ration $+1 \%$ residue of pupae powder extraction, R4= isoenergy and isoprotein ration $+10 \%$ residue of pupae powder extraction, $\mathrm{R} 5=$ isoenergy and isoprotein ration $+1 \%$ pupae powder, and $\mathrm{R} 6=$ isoenergy and isoprotein ration $+10 \%$ pupae powder. Pupae powder was used as a feed supplement with doses of $0 \%$ (control), 1\% and 10\% (Ohta et al., 2014). Parameters measured were blood profile of the experimental quails consisted of number of erythrocytes, hemoglobin concentration, hematocrit percentage, leukocyte count and leukocyte differentiation (Jalees et al., 2011). Blood samples of quail were taken on the $15^{\text {th }}$ day at the time of observation 12,24 , and $48 \mathrm{~h}$. It was based on the estimation that time of circulating white blood cells in the blood may be brief (Guyton \& Hall, 1997). Blood sampling at different times was conducted in order to look at the treatment that had significantly impacted on the number of white blood cells. One milliliters of blood sample was taken and put into EDTA tubes. Preparations of the blood smear with Giemsa

Table 1. Composition and nutrient contents of the basal ration in laying period

\begin{tabular}{lr}
\hline Feed ingredient & $(\%)$ \\
\hline Yellow corn & 50.13 \\
Soybean meal & 23.00 \\
Fish meal & 8.00 \\
Rice bran & 6.87 \\
Palm oil & 4.50 \\
CaCO & 6.60 \\
Premix & 0.50 \\
DL=Methionine & 0.20 \\
NaCl & 0.20 \\
Total & 100.00 \\
Nutrient content $\left.{ }^{*}\right)$ & \\
Metabolizable energy (kkal/kg) & 2950.08 \\
Crude protein (\%) & 18.82 \\
Crude fat (\%) & 5.36 \\
Crude fiber (\%) & 2.41 \\
Methionine (\%) & 0.58 \\
Lysine (\%) & 1.06 \\
Cystine (\%) & 0.30 \\
Linoleic acid (\%) & 1.50 \\
Ca (\%) & 3.19 \\
P (\%) & 0.48 \\
Na (\%) & 0.15 \\
Cl (\%) & 0.17 \\
\hline & \\
\hline & \\
\hline
\end{tabular}

Note: "Based on calculation using the formula of Leeson \& Summers (2005) staining were made to calculate the number of leukocyte. Total white blood cells and total red blood cells were calculated by using a Neubauer hemocytometer, with a modified diluent solution of Rees \& Ecker. Data were tested by using Analysis of Variance (ANOVA) and the differences among treatments' means were examined by Duncan Multiple Range Test (Mattjik \& Sumertajaya, 2002). Data were processed by using SPSS 16.0 statistical software.

\section{RESULTS AND DISCUSSION}

\section{Quail Feed Consumption}

Feed consumption during the research ranged from $79.19 \mathrm{~g} /$ quail/wk to $154.70 \mathrm{~g} /$ quail/wk (Table 2). The results showed that the supplementation of pupae extract, residue of pupae extraction and pupae powder in R1, R2, R3, R4, R5, and R6 did not affect the average feed consumption. In poultry, there is a limiting factor of feed intake that is the gizzards capacity and energy requirements (North \& Bell, 1990). The limiting factors cause quail stop eating when energy needs are fulfilled. Feed given during the study was in accordance with the needs of quail that have been specified in SNI (1995) with energy content of $2900 \mathrm{kcal} / \mathrm{kg}$. Quail used in this study had the same age, namely four weeks so that the gizzards size was not much different. This caused the feed intake of all treatments was not different, except in $\mathrm{R} 2$ treatment (extract pupae powder with dose of 10\%).

\section{Quail Body Weight}

The observation during the experiment found that the body weight gain of quails from the beginning to the end of experiment increased in quails fed with R2 treatment (extract of pupae powder at a dose of 10\%) (Table 3 ). The provision of pupae powder in extract form as a force feeding enable all of the ingredients entered the body of quails through gastrointestinal tract without being wasted. Silkworm pupae powder in the form of polysaccharide extract contains active ingredients that can boost the immune system of the experimental quails. These results are consistent with the results reported by Ido et al. (2015), that the administration of extract of house fly pupae powder in red sea bream fish improved growth rate and immune system.

\section{Total Number of Erythrocytes}

The results showed that the number of erythrocyte in the group R1, R2, R3, R4, R5, and R6 were similar $(P>0.05)$ (Table 4). Erythrocytes are blood cells that have a nucleus and play a role in carrying hemoglobin to bind oxygen throughout the body. The ranges of average erythrocytes number of laying quail studied were $2.97-3.46 \times 10^{6} / \mathrm{mm}^{3}$. This value was still in the normal range. According to Sturkie \& Griminger (1976), the normal number of erythrocytes is 2.30-3.86 x $10^{6} / \mathrm{mm}^{3}$. This indicates that the active ingredient contained in pupae powder extract, pupae powder residue and pupae powder in the form of polysaccharides silkrose did not 
Table 2. Average feed consumption of quails during experiment $(\mathrm{g} / \mathrm{bird} / \mathrm{wk})$

\begin{tabular}{ccccccccc}
\hline \multirow{2}{*}{ Treatments } & \multicolumn{7}{c}{ Weeks } \\
\cline { 2 - 9 } & 1 & 2 & 3 & 4 & 5 & 6 & 7 & 8 \\
\hline R0 & $79.67 \pm 0.40$ & $81.00 \pm 0.33$ & $90.04 \pm 0.68$ & $97.27 \pm 0.99$ & $100.04 \pm 0.72$ & $120.01 \pm 0.17$ & $134.20 \pm 0.42$ & $140.01 \pm-0.52$ \\
R1 & $80.04 \pm 0.61$ & $81.19 \pm 0.16$ & $92.52 \pm 0.32$ & $98.02 \pm 0.48$ & $101.22 \pm 0.28$ & $120.14 \pm 0.41$ & $135.47 \pm 0.19$ & $140.11 \pm 0.33$ \\
R2 & $81.36 \pm 0.13$ & $85.29 \pm 0.19$ & $94.52 \pm 0.46$ & $100.28 \pm 0.21$ & $130.16 \pm 0.37$ & $140.44 \pm 0.18$ & $149.12 \pm 0.13$ & $154.70 \pm 0.32$ \\
R3 & $79.52 \pm 0.15$ & $80.79 \pm 0.21$ & $89.67 \pm 0.67$ & $97.13 \pm 0.38$ & $100.02 \pm 0.42$ & $120.00 \pm 0.29$ & $134.01 \pm 0.78$ & $137.15 \pm 0.51$ \\
R4 & $79.86 \pm 0.58$ & $82.71 \pm 0.62$ & $90.19 \pm 0.81$ & $97.45 \pm 0.37$ & $100.17 \pm 0.28$ & $121.46 \pm 0.61$ & $134.27 \pm 0.43$ & $140.08 \pm 0.62$ \\
R5 & $79.21 \pm 0.17$ & $80.34 \pm 0.12$ & $89.22 \pm 0.10$ & $97.08 \pm 0.92$ & $100.00 \pm 0.71$ & $119.47 \pm 0.57$ & $133.98 \pm 0.18$ & $137.13 \pm 0.49$ \\
R6 & $79.19 \pm 0.35$ & $80.21 \pm 0.67$ & $89.16 \pm 0.15$ & $97.01 \pm 0.21$ & $99.71 \pm 0.34$ & $119.15 \pm 0.13$ & $133.12 \pm 0.68$ & $136.05 \pm 0.86$ \\
\hline
\end{tabular}

Note: $\mathrm{R} 0=$ ration without pupae powder extract (control), $\mathrm{R} 1=$ ration $+1 \%$ pupae powder extract, $\mathrm{R} 2=$ ration $+10 \%$ pupae powder extract, $\mathrm{R} 3=$ ration + $1 \%$ residue of pupae powder extraction, $\mathrm{R} 4=$ ration $+10 \%$ residue of pupae powder extraction, $\mathrm{R} 5=$ ration $+1 \%$ pupae powder, and $\mathrm{R} 6=$ ration + $10 \%$ pupae powder

Table 3. Average body weight gain of quails during experiment $(\mathrm{g} / \mathrm{bird})$

\begin{tabular}{ccccccccc}
\hline \multirow{2}{*}{ Treatments } & \multicolumn{7}{c}{ Weeks } \\
\cline { 2 - 8 } & 1 & 2 & 3 & 4 & 5 & 6 & 7 & 8 \\
\hline R0 & $72.10 \pm 0.27$ & $75.28 \pm 1.15$ & $80.12 \pm 1.14$ & $85 \pm 2.12$ & $95.87 \pm 0.53$ & $109 \pm 0.42$ & $124 \pm 0.12$ & $139 \pm-1.11$ \\
R1 & $72.13 \pm 1.69$ & $75.14 \pm 0.32$ & $80.09 \pm 1.25$ & $87.00 \pm 1.13$ & $97.89 \pm 0.22$ & $118 \pm 0.23$ & $127 \pm 1.28$ & $142 \pm 1.34$ \\
R2 & $72.13 \pm 0.48$ & $75.07 \pm 0.19$ & $80.14 \pm 1.09$ & $87.30 \pm 0.49$ & $98.58 \pm 0.14$ & $121 \pm 1.47$ & $138 \pm 0.45$ & $149 \pm 2.12$ \\
R3 & $72.03 \pm 1.13$ & $75.15 \pm 0.21$ & $80.23 \pm 0.47$ & $86.30 \pm 0.18$ & $96.87 \pm 0.67$ & $110 \pm 2.23$ & $124 \pm 1.47$ & $138 \pm 0.45$ \\
R4 & $71.89 \pm 1.25$ & $75.02 \pm 0.11$ & $79.45 \pm 0.56$ & $86.00 \pm 1.23$ & $96.45 \pm 0.72$ & $105 \pm 2.12$ & $125 \pm 1.13$ & $139 \pm 1.18$ \\
R5 & $72.34 \pm 0.43$ & $75.18 \pm 0.41$ & $80.17 \pm 0.68$ & $85.59 \pm 0.57$ & $95.98 \pm 0.54$ & $115 \pm 0.61$ & $130 \pm 1.26$ & $138 \pm 0.67$ \\
R6 & $71.45 \pm 0.34$ & $75.11 \pm 0.27$ & $80.00 \pm 1.11$ & $85.47 \pm 0.81$ & $96.43 \pm 2.13$ & $117 \pm 1.14$ & $128 \pm 1.16$ & $137 \pm 0.45$ \\
\hline
\end{tabular}

Note: $\mathrm{R} 0=$ ration without pupae powder extract (control), $\mathrm{R} 1=$ ration $+1 \%$ pupae powder extract, $\mathrm{R} 2=$ ration $+10 \%$ pupae powder extract, $\mathrm{R} 3=$ ration + $1 \%$ residue of pupae powder extraction, $\mathrm{R} 4=$ ration $+10 \%$ residue of pupae powder extraction, $\mathrm{R} 5=$ ration $+1 \%$ pupae powder, and $\mathrm{R} 6=$ ration + $10 \%$ pupae powder

Table 4. Mean of erythrocytes, hemoglobin, hematocrit, and leukocytes number in quail blood during experiment

\begin{tabular}{|c|c|c|c|c|c|c|c|c|}
\hline & \multicolumn{8}{|c|}{ Treatments } \\
\hline & R0 & R1 & $\mathrm{R} 2$ & R3 & $\mathrm{R} 4$ & R5 & R6 & Standard* \\
\hline $\begin{array}{l}\text { Erythrocyte number } \\
\left(10^{6} / \mathrm{mm}^{3}\right)\end{array}$ & $3.24 \pm 0.27$ & $3.39 \pm 0.32$ & $3.05 \pm 0.38$ & $3.46 \pm 0.29$ & $3.22 \pm 0.20$ & $2.97 \pm 0.35$ & $3.39 \pm 0.16$ & $2-3.86$ \\
\hline $\begin{array}{l}\text { Hemoglobin level } \\
(\mathrm{g} \%)\end{array}$ & $9.94 \pm 1.69$ & $9.75 \pm 2.60$ & $12.21 \pm 2.42$ & $7.57 \pm 1.57$ & $12.23 \pm 1.88$ & $10.83 \pm 2.23$ & $10.03 \pm 1.66$ & $7-13$ \\
\hline Hematocrit value (\%) & $33.56 \pm 1.74$ & $32.09 \pm 1.30$ & $35.18 \pm 1.53$ & $29.42 \pm 2.31$ & $33.34 \pm 2.30$ & $33.94 \pm 2.29$ & $31.13 \pm 2.12$ & $30-37$ \\
\hline $\begin{array}{l}\text { Leukocyte number } \\
\left(10^{3} / \mathrm{mm}^{3}\right)\end{array}$ & $3.77 \pm 0.46^{\mathrm{a}}$ & $6.93 \pm 0.09^{a}$ & $14.22 \pm 0.04^{\mathrm{b}}$ & $4.13 \pm 1.85^{\mathrm{a}}$ & $6.44 \pm 1.32^{\mathrm{a}}$ & $3.55 \pm 0.41^{a}$ & $3.97 \pm 0.98^{\mathrm{a}}$ & $20-40$ \\
\hline
\end{tabular}

Note: Means in the same row with different superscripts differ significantly $(\mathrm{P}<0.05)$. ${ }^{*}$ Based on Sturkie \& Griminger $(1976)$.

$\mathrm{R} 0=$ ration without pupae powder extract (control), $\mathrm{R} 1=$ ration $+1 \%$ pupae powder extract, $\mathrm{R} 2=$ ration $+10 \%$ pupae powder extract, $\mathrm{R} 3=\mathrm{ration}+$ $1 \%$ residue of pupae powder extraction, $\mathrm{R} 4=$ ration $+10 \%$ residue of pupae powder extraction, $\mathrm{R} 5=$ ration $+1 \%$ pupae powder, and $\mathrm{R} 6=$ ration + $10 \%$ pupae powder.

inhibit the formation of erythrocytes, thus laying quail conditions were healthy.

\section{Level of Hemoglobin}

The results showed that the hemoglobin concentrations in the quails fed with ration R1, R2, R3, R4, R5, and R6 were not different $(\mathrm{P}>0.05)$ (Table 4). Hemoglobin closely related to the erythrocyte and hematocrit. Hemoglobin is a simple protein, red color poster on erythrocytes, and function in the binding of oxygen. Hemoglobin concentrations of the experimental quails ranged from $7.57 \%$ to $12.23 \mathrm{~g} \%$. These hemoglobin values are still in the normal range. According to Sturkie \&
Griminger (1976), the normal hemoglobin level is 12.30 g\%.

\section{Value of Hematocrit}

The results of the variance analysis showed that the hematocrit values of the experimental quails fed with ration $\mathrm{R} 1, \mathrm{R} 2, \mathrm{R} 3, \mathrm{R} 4, \mathrm{R} 5$, and $\mathrm{R} 6$ were not different $(\mathrm{P}>0.05)$ (Table 4$)$. Hematocrit value is a term that means the percentage (by volume) of blood that consists of red blood cells after being centrifuged (Fradson, 1992). Hematocrit value is influenced by the number and size of red blood cells (Sturkie \& Griminger, 1976). Hematocrit values in this study ranged from $29.42 \%-$ 
$35.18 \%$. The hematocrit values were in the normal range. According to Sturkie \& Griminger (1976), the normal hematocrit value in quail is $37 \%$.

Hematocrit values indicate the total number of erythrocytes in the blood, thus becoming one of the indicators of the determination of the blood ability to carry oxygen (O2) which are commonly known as Oxygen Carrying Capacity (Maheswaran et al., 2008).

Decrease in hematocrit value can be caused by several other factors, namely the level of stress by environmental influences and nutrition, dehydration and parasites in the blood (Challenger et al., 2001). During the maintenance of experimental laying quail, ambient temperature tended to be high, ranging from $31-33^{\circ} \mathrm{C}$. Heat stress can occur when the ambient temperature exceeds $32^{\circ} \mathrm{C}$ (Hemid et al., 2010). The condition causes laying quail consume more water. The high consumption of drinking water causes the water concentration in the blood increases, thereby decreasing the percentage of blood (hematocrit) (Tamzil et al., 2013). It can also be caused by the high levels of yolk precursors (William et al., 2004), and due to the increased concentrations of estrogen in the blood (Wagner et al., 2008), an assumption that illustrates the decline in quail's hematocrit concentrations with higher egg production.

\section{Number of Leukocytes}

Further test results indicated that averages numbers of leukocytes of the control group were similar to those of R1, R3, R4, R5, and R6 groups (Table 4). However, the R2 group quails had significantly $(\mathrm{P}<0.05)$ higher leukocyte numbers as compared to the other treatments $\left(14.22 \times 10^{3} / \mathrm{mm}^{3}\right)$. The increased number of leukocyte occurred at the $24 \mathrm{~h}$ after observation and decreased at $48 \mathrm{~h}\left(9.86 \times 10^{3} / \mathrm{mm}^{3}\right)$ (Figure 1). The ranges of average number of leukocytes in the control (R0), R1, R2, R3, R4, R5, and R6 were 3.55 to $14.22 \times 10^{3} / \mathrm{mm}^{3}$ and this range was lower but still under the normal range. According to Sturkie \& Griminger (1976), the normal leukocyte count in quail ranges from 20 to $40 \times 10^{3} / \mathrm{mm}^{3}$.

The number of leukocytes in this study tended to be lower compared to a standard leukocyte count in quail. This lower number of leukocyte was due to the state of heat stress because the ambient temperature during the experiment was in the range of $31-33^{\circ} \mathrm{C}$. The decrease in the leukocytes number in the experimental laying quail in this study was approximately $50 \%$ when compared to standard quail leukocytes that were not in stress conditions (Table 3). Tamzil et al. (2014) reported that the levels of leukocytes in chickens decreased by $40 \%$ at the time of heat stress. Heat stress decreased the number of leukocytes so that the immune system became lower (Kusnadi, 2009; Usama et al., 2013). Muhammad (2013) stated that during stress the number of leukocytes and lymphocytes decreased as well as improving the ratio of $\mathrm{H} / \mathrm{L}$, which is one important indicator of stress in laying quail, especially during the laying period. Blood sampling in this research was performed at 7 weeks of age at the beginning of laying eggs. Female quails start laying eggs at the age of 6 weeks (Sujana et al., 2012). Blood sampling was conducted at 12,24 , and $48 \mathrm{~h}$ after giving the treatment.

Leukocyte is an active unit to provide fast and powerful defense against any material that causes infection (Guyton \& Hall, 1997). Leukocytes play a role in responding the immune. The use of silkworm pupa powder was able to maintain the number of leukocytes in laying quails for functioning the immune system, because the silkworm pupae powder contained polysaccharides silkrose which could boost immune function. Polysaccharides silkrose of silkworm pupae could significantly increase macrophage phagocytosis and increase hemolysin antibody and lymphocyte transformation. This indicates that polysaccharide of silkworm pupae clearly indicate the presence of nonspecific immunity (innate immunity) (Sun et al., 2007). Ethanol extraction could improve the content of polysaccharides found in insect pupae (Liu \& Zhang, 2006). Polysaccharides silkrose contained in the $10 \%$ of pupae powder extract was assumed can increase the number of laying quail leukocytes which were experiencing stress on the production period. According to Hrabcakova et al. (2014), a lot of factors that affect the levels of leukocytes in poultry i.e., genetic (species and strains), exposure to stress (stress may be temperature, environment uncomfortable cage, handling), system maintenance, feed, production period (starter, grower, layer) and the lighting program.

\section{Leukocyte Differentiation}

In this study, the number of heterophile, lymphocytes, and monocytes were observed at 12,24 , and 48 h. This was done to document the effect of treatment on the immune responses by counting white blood cell types. The results of the variance analysis showed that R1, R2, R3, R4, R5, and R6 groups did not have significant different number of heterophile in laying quail blood (Table 5). The average number of heterophile

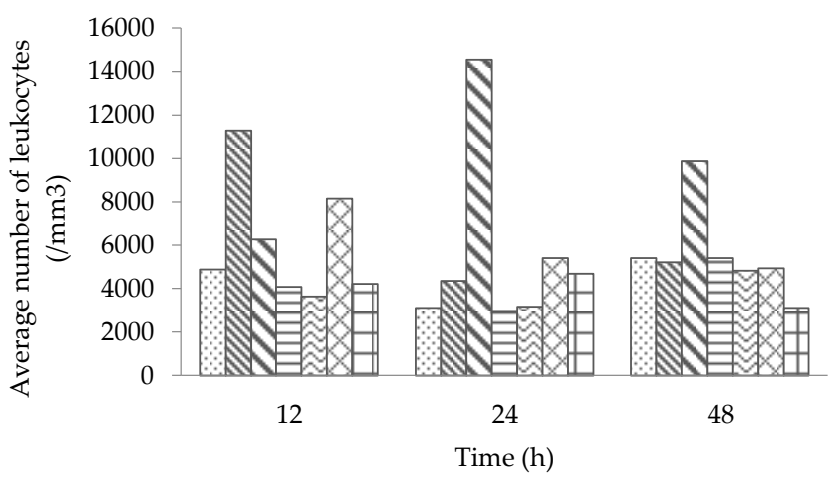

Figure 1. Average number of leukocytes in the experimental of quail blood at different sampling time. $\nabla R 0 \otimes R 1 \Delta R 2 \boxminus R 3 \quad \square R 4 \otimes R 5 \quad \boxminus R 6 . \quad R 0=$ ration without pupae powder extract (control), R1= ration $+1 \%$ pupae powder extract, $\mathrm{R} 2=$ ration $+10 \%$ pupae powder extract, $\mathrm{R} 3=$ ration $+1 \%$ residue of pupae powder extraction, $\mathrm{R} 4=$ ration $+10 \%$ residue of pupae powder extraction, $\mathrm{R} 5=$ ration $+1 \%$ pupae powder, and $\mathrm{R} 6=$ ration $+10 \%$ pupae powder. 
in quail blood in the study ranged between $22.33 \%$ and $41.55 \%$. The number of heterophile in this study was quite high, indicating quail treated R1, R2, R3, R4, R5, and R6 had good immune responses. Sturkie \& Griminger (1976) stated that the percentage of normal quail heterophile ranged between 20\%-30\%. In this study, the number of heterophile increased at the $12^{\text {th }}$ hour and then decreased until the $48 \mathrm{~h}$ of observation in the groups R2, R3, R4, and R5 (Figure 2).

The results of variance analysis showed that groups R1, R2, R3, R4, R5, and R6 did not have significantly different in number of lymphocytes in the quail blood studied. The range of lymphocytes in this study was $46.89 \%$ to $75.55 \%$ (Table 5). Lymphocyte values in this study were quite high, indicating that quail in the groups of R1, R2, R3, R4, R5, and R6 had a good immune desist. Sturkie \& Griminger (1976) stated that the percentage of quail lymphocytes normally ranged between $30 \%-66 \%$. In this study, the number of lymphocytes increased until the $24 \mathrm{~h}$, although decreased in the 48 h (Figure 2). Lymphocytes have very important roles in the immune system (Melvin et al., 1993).

The results of variance analysis showed that treatment of R1, R2, R3, R4, R5, and R6 did not affect the number of monocytes in the quail blood. Monocytes in this study ranged $0.33 \%-3.67 \%$. This indicated that there was no an acute infection in quail under the treatment of R1, R2, R3, R4, R5, and R6. This situation indicated the status of quail was in a healthy state. Sturkie \& Griminger (1976) states that the percentage of quail monocytes normally range between $0 \%-8.1 \%$. In this study, the number of monocytes increased in the $12^{\text {th }}$ $\mathrm{h}$ up to $48^{\text {th }} \mathrm{h}$, in the treatment of R1 and R2 (Figure 2). Polysaccharides silkrose that enters the body is regarded

Table 5. Percentage of leukocytes differentiation of laying quail during experiment

\begin{tabular}{lcccccccc}
\hline & \multicolumn{9}{c}{ Treatments } \\
\cline { 2 - 8 } & R0 & R1 & R2 & R3 & R4 & R5 & R6 & Standard \\
\hline Heterophiles & $37.33 \pm 0.27$ & $37.80 \pm 0.06$ & $30.79 \pm 0.42$ & $36.00 \pm 0.41$ & $36.53 \pm 0.46$ & $40.34 \pm 0.10$ & $40.22 \pm 0.45$ & $20-30$ \\
Lymphocytes & $61.34 \pm 0.28$ & $60.20 \pm 0.12$ & $64.55 \pm 0.83$ & $62.00 \pm 0.43$ & $61.58 \pm 0.64$ & $57.00 \pm 0.31$ & $59.45 \pm 0.40$ & $30-66$ \\
Monocytes & $1.33 \pm 0.33$ & $2.00 \pm 0.09$ & $3.67 \pm 0.52$ & $2.00 \pm 0.47$ & $1.89 \pm 0.38$ & $2.66 \pm 0.11$ & $0.33 \pm 0.33$ & $0-8.1$ \\
Basophiles & - & - & $0.33 \pm 0.33$ & - & - & - & - & $0-2$ \\
Eosinophiles & - & - & $0.66 \pm 0.43$ & - & - & - & - & $0-3$ \\
H/L & $0.61 \pm 0.15$ & $0.63 \pm 0.10$ & $0.48 \pm 0.06$ & $0.58 \pm 0.17$ & $0.60 \pm 0.12$ & $0.70 \pm 0.18$ & $0.68 \pm 0.15$ & $0.34-0.43$ \\
\hline
\end{tabular}

Note: *Based on Sturkie \& Griminger (1976). R0= ration without pupae powder extract (control), R1= ration $+1 \%$ pupae powder extract, R2= ration + $10 \%$ pupae powder extract, $\mathrm{R} 3=$ ration $+1 \%$ residue of pupae powder extraction, $\mathrm{R} 4=$ ration $+10 \%$ residue of pupae powder extraction, $\mathrm{R} 5=$ ration $+1 \%$ pupae powder, and $\mathrm{R} 6=$ ration $+10 \%$ pupae powder.
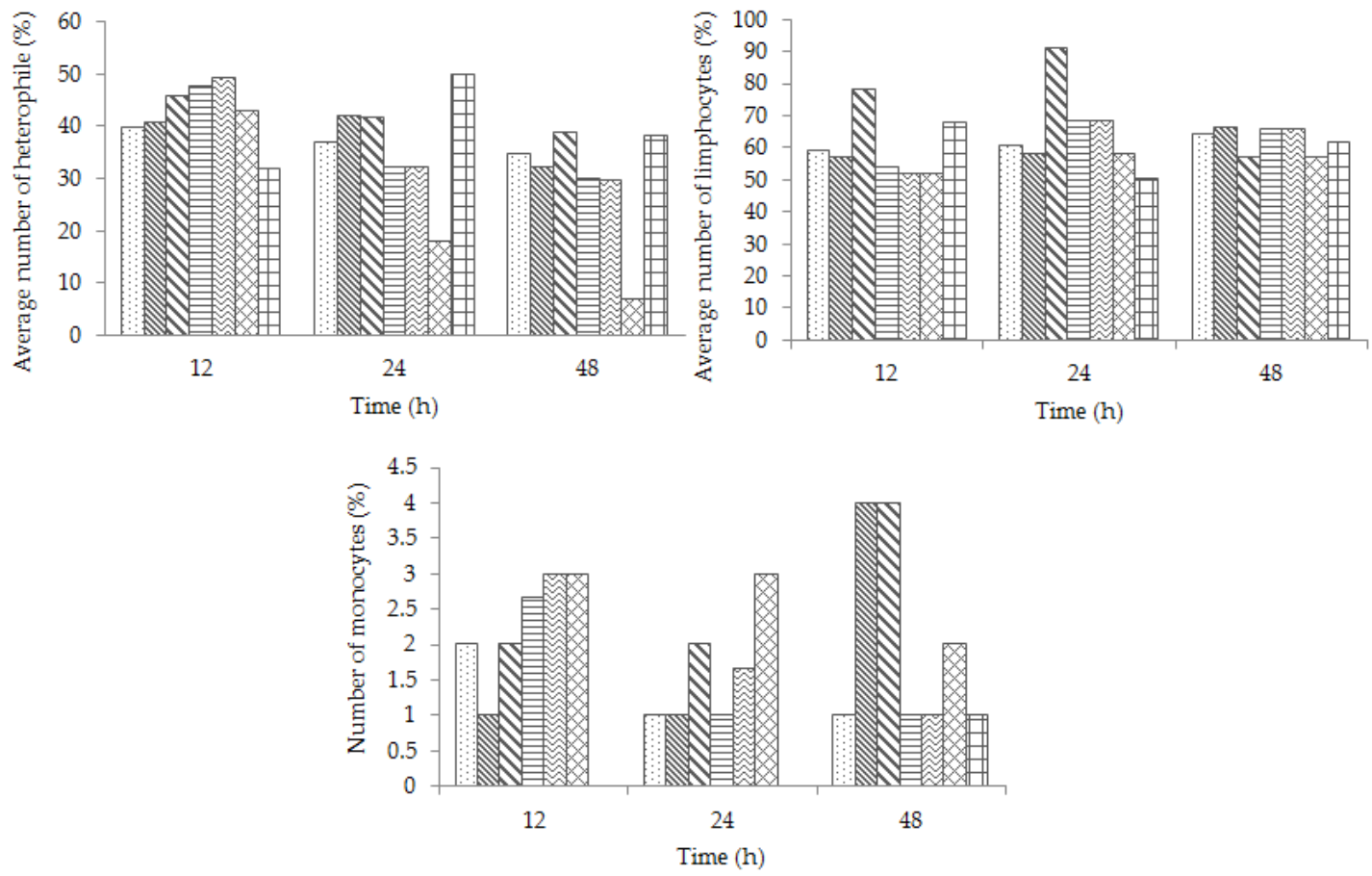

Figure 2. Leukocytes differentiation in the experimental of quail blood heterophiles, limphocytes, and monocytes at different sampling time. The treatments were $\mathrm{R} 0=$ ration without pupae powder extract (control), $\mathrm{R} 1=$ ration $+1 \%$ pupae powder extract, $\mathrm{R} 2=\mathrm{ra}-$ tion $+10 \%$ pupae powder extract, $\mathrm{R} 3=$ ration $+1 \%$ residue of pupae powder extraction, $\mathrm{R} 4=$ ration $+10 \%$ residue of pupae pow-

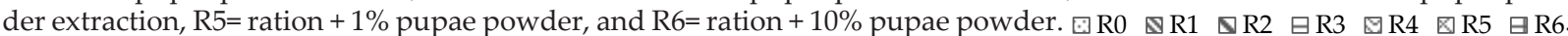


as a foreign body, so it will attract monocyte through its phagositic capabilities. Monocytes are an essential component of the innate immunity (Parihar et al., 2010).

\section{CONCLUSION}

Total leukocyte of laying quail in this study significantly increased in quail treated with the addition of extract pupae powder with dose of $10 \%$ in the ration. The increase of leukocytes number occurred at the $24 \mathrm{~h}$, and then decreased at $48 \mathrm{~h}$ after observation. The addition of silkworm pupae powder extracts containing polysaccharides' silkrose in the ration could increase the number of leukocytes in laying quail at heat stress conditions.

\section{REFERENCES}

Astuti, T.\& C. M. Kusharto. 2009. Tepung pupa-mulberry (pury) sebagai bahan pangan alternatif kaya gizi. J. Giz. Pangan. 4:29-32.

Bomford, R. 1980. Saponin and other haemolysins (vitamin A, aliphatic amines, polyene antibiotics) as adjuvant for SRBC in the Mouse. Evidence for a role for cholesterol binding in saponin adjuvanticity. Intl. Arch. Alergy Appl. Immunol. 63:170-7. http://dx.doi.org/10.1159/000232623

Challenger, W. O., T. D. Williams, J. K. Christians, \& F. Vejina. 2001. Follicular development and plasma yolk precursors dynamics through the laying cycle in the European starling (Sturnus vulgaris). Physiol. Biochem. Zool. 74:356-365. http://dx.doi.org/10.1086/320427

Chernysh, S., S. I. Kim, G. Bekker, V. A. Pleskach, \& N. A. Filatova. 2002. Antiviral and antitumor peptides from insects. Proc. Natl. Acad. Science USA. 99:12628-32. http://dx.doi. org/10.1073/pnas.192301899

Fradson, R. D. 1992. Anatomi dan Fisiologi Ternak. Ed Ke-4. Gajah Mada University Press, Yogyakarta.

Guyton, A. C. \& J. E. Hall. 1997. Sel Darah Merah, Anemia, dan Polisitimia. Di dalam: Fisiologi Kedokteran. Penerjemah; Irawati, Tengadi LMA, Santoso A. Penerbit Buku Kedokteran EGC Press, Jakarta. Hlm 93-130.

Hemid, A. E. A., A. H. A. El-Gawad, I. El-Wardany, F.E. El-Daly, \& A. N. A. El-Azeem 2010. Alleviating effect of some environmental stress factors on productive performance in Japanese Quail 2. Laying performance. World. Journal. Agri. Sciences. 6:517-524

Hirose, Y., E. Ohta, Y. Kawai, \& S. Ohta. 2013. Dorsamin-A's, glycerolipids carrying a Dehydrophenylalanine Ester Moiety from the seed-eating larvae of the Bruchid Beetle Bruchidius dorsalis. J. Nat. Prod. 76:554-558. http://dx.doi. org/10.1021/np300713c

Hrabcakova, P., E. Voslarova, I. Bedanova, V. Pistekova, \& J. Chloupek. 2014. Changes in selected haematological and biochemical parameters in debeaked pheasant hens during the laying period. Ankara Univ. Vet. Fak. Derg. 61:111117. http://dx.doi.org/10.1501/Vetfak_0000002614

Huis, A.V., J. V. Itterbeeck, H. Klunder, E. Mertens, A. Halloran, G. Muir, \& P. Vantomme. 2013. Edible Insects: Future prospects for food and feed security. FAO, Rome, Italy. pp. 187.

Ido, A., T. Iwai, K. Ito, T. Ohta, T. Mizushige, T. Kishida, C. Miura, \& T. Miura. 2015. Dietary effects of housefly (Musca domestica) (Diptera: Muscidae) pupae on the growth performance and the resistance against bacterial pathogen in the red sea bream (Pagrus major) (Perciformes: Sparidae). Appl. Entomol. Zool. 50: 213-221. http://dx.doi. org/10.1007/s13355-015-0325-z
Jalees, M. M., M. Z. Khan, M. K. Saleemi, \& A. Khan. 2011. Effects of cottonseed meal on hematological, biochemical and behavioral alterations in male Japanese quail (Coturnix japonica). Pakistan Vet. Journal. 31:211-214.

Kusnadi, E. 2009. Perubahan malonaldehida hati, bobot relatif bursa fabricius dan rasio Heterofil/Limfosit $(\mathrm{H} / \mathrm{L})$ ayam broiler yang diberi cekaman panas Med. Pet. 32:81-87.

Leeson, S. \& J. D. Summers. 2005. Commercial Poultry Nutrition. $3^{\text {rd }}$ ed. Guelph Univ., Canada.

Liu, G. Q. \& K. C. Zhang. 2006. Effects of water and ethanol extracts of insects on polysaccharide production by submerged fermentation of Ganoderma lucidum. Mycosystema. 25:308-315.

Long, S., F. Ying, H. E. Zhao, M. A. Tao, \& Z. Xin. 2007. Studies on Alkaline solution extraction of polysaccharide from silkworm pupa and its immunomodulating activities. Forest Res. 20:782-786.

Maheswaran, R., A. Devapaul, S. Muralidhalan. B. Velmurugan, \& S. Ignacimuthu. 2008. Haematological studies of fresh water fish, clarais batrachus (I.) exposed to mercuric chloride International Journal of Integrative Biol. 2:49.

Mattjik, A. A. \& M. Sumertajaya. 2002. Perancangan Percobaan dan Aplikasi SAS dan Minitab. Jilid I. Edisi ke-2. IPB Press, Bogor.

Melvin, J. S. \& O. R. William. 1993. Duke's Physiology of Domestic Animals. $11^{\text {th }}$ ed. Cornell University Press, London.

Muhammad, H.K. 2013. Study the effect of age and sex on some haemotological parameters in Golden Local Quail. Bas. J. Vet. Res. 12:135-141.

North, M.O. \& D. D. Bell. 1990. Commercial Chicken Production Manual. $4^{\text {th }}$ Ed. Van Nostrand Reinhold, New York.

Oh, H. G., H. Y. Lee, J. H. Kim, Y. R. Kang, D. I. Moon, M. Y. Seo, H. I. Back, S. Y. Kim, M. R. Oh, S. H. Park, M.G. Kim, J Y. Jeon, S. J. Shin, K.S. Ryu, S.W. Chae, O. Kim, \& J. K. Park. 2012. Effect of male silkworm pupae powder on the erectile dysfunction by chronic ethanol consumption in rats. Lab Anim. Res. 28:83-90. http://dx.doi.org/10.5625/ lar.2012.28.2.83

Ohta, T., A. Ido, K. Kusano, C. Miura, \& T. Miura. 2014. A novel polysaccharide in insects activates the innate immune system in mouse macrophage RAW264 cells. PLoS ONE. 9:e114823. http://dx.doi.org/10.1371/journal.pone.0114823

Parihar, A., T. D. Eubank, \& A. I. Doseff. 2010. Monocytes and machropages regulate immunity through dynamics networks of survival and cell death. J. Innate Immun. 2:204205. http://dx.doi.org/10.1159/000296507

Rumpold, B. A. \& O. K. Schluter. 2013. Nutritional composition and safety aspects of edible insects. Mol. Nutr. Food Res. 57:802-23. http://dx.doi.org/10.1002/mnfr.201200735

Standar Nasional Indonesia, 01-3906-1995. Ransum Puyuh Petelur Dara (Quail Grower)

Standar Nasional Indonesia, 01-3907-1995. Ransum Puyuh Petelur Dewasa (Quail Layer)

Sturkie, P.D. \& P. Griminger. 1976. Blood : physical characteristics, formed elements, hemoglobin and coagulation. 3rd ed. Springer, Verlag.

Sujana E., W. Tanwiriah, \& T. Widjastuti. 2012. Evaluation on Quails (Coturnix coturnix japonica) growth performance among the breeding centre of village communities in West Java. J. Zootehnie. 58:70-72.

Sun, L., Y. Feng, Z. HE, T. Ma, \& X. Zhang. 2007. Studies on alkaline solution extraction of polysaccharide from silkworm pupa and its immunomodulating activities. Forest Research. 20:782-786.

Swevers, L., G. Smagghe, \& J. Liu. 2013. Transcriptional response of BmToll9-1 and RNAi machinery genes to exogenous dsRNA in the midgut of Bombyx mori. Journal of Insect Physiol. 59:646-654. http://dx.doi.org/10.1016/j.jinsphys.2013.03.013 
Tamzil, M. H., R.. R. Noor, P. S. Hardjosworo, W. Manalu, \& C. Sumantri. 2013. Keragaman gen heat shock protein 70 ayam Kampung, ayam Arab dan ayam Ras. Journal Vet. 14:317-326.

Tamzil, M. H., R.. R. Noor, P. S. Hardjosworo, W. Manalu, \& C. Sumantri. 2014. Hematological response of chickens with different heat shock protein 70 genotypes to acute heat stress. Int. J. Poult. Sci. 13:14-20. http://dx.doi.org/10.3923/ ijps.2014.14.20

Tomotake, H., M. Katagiri, \& M. Yamamoto. 2010. Silk worm pupae (Bombyx mori) are new source of heigh quality protein and lipid. Journal Nutr. Sci. Vitamin. 56:446-448. http://dx.doi.org/10.3177/jnsv.56.446

Usama, T. M., A. A. Mootaz, H. D. Madeha, \& G. M. Mosaad. 2013. The effect of heat stress on blood picture of japanese quail. Journal of Advanced Vet. Res. 3:69-76.

Usub, T., C. Lertsatitthanakorn, N. Poomsa-ad, L. Wiset, L. F. Yang, \& S. Siriamornpun. 2008. Experimental performance of a solar tunnel dryer for drying silkworm pupae. Biosyst. Eng. 101:209-216. http://dx.doi.org/10.1016/j.biosystemseng.2008.06.011

Vantomme P. 2010. Edible forest insects, an overlooked protein supply: Worldwide, over 1.400 insect species are reportedly eats as human food; most harvested from natural forest. Unasylva. 236:19-21.
Wagner, C. E., J. S. Prevolsek, K. E. Wynne, \& T. D. Williams. 2008. Hematological changes associated with egg production: estrogen dependence and repeatibility. J. Exp. Biol. 211:400-408. http://dx.doi.org/10.1242/jeb.011205

Williams, T. D., W. O. Challenger, J. K. Christians, M. Evanson, O. Love, \& F. Vezina. 2004. What causes the decrease in hematokrit during egg production?. Func. Eco. 18:330336. http://dx.doi.org/10.1111/j.0269-8463.2004.00829.x

Yao, H., X. Wu, \& K. Gokulamma. 2006. Antiviral activity in the mulberry silkworm, Bombyx mori L. Journal of Zhejiang Univ. SCIENCE A. 7:350-356. http://dx.doi.org/10.1631/ jzus.2006.AS0350

Yeo, Y., M. Cho, B. Jeon, H. Seo, T. Kwon, \& S. Ryu. 2013. Changes of pupae powder ingestion on inflammatory cytokine in rats. J. Exerc. Nutr. Biochem. 17:71-80. http:// dx.doi.org/10.5717/jenb.2013.17.3.71

Yi, C., Q. He, L. Wang, R. Kuang. 2010. The utilization of insect-resources in Chinese rural area. J. Agri. Sci. 2: 146-154. http://dx.doi.org/10.5539/jas.v2n3p146

Zhou J. \& D. Han. 2006. Safety evaluation of protein of silkworm (Antheraea pernyi) pupae. Food Chem. Toxicol. 44:1123-1130. http://dx.doi.org/10.1016/j.fct.2006.01.009 